\title{
Does John 17:11b, 21-23 refer to church unity?
}

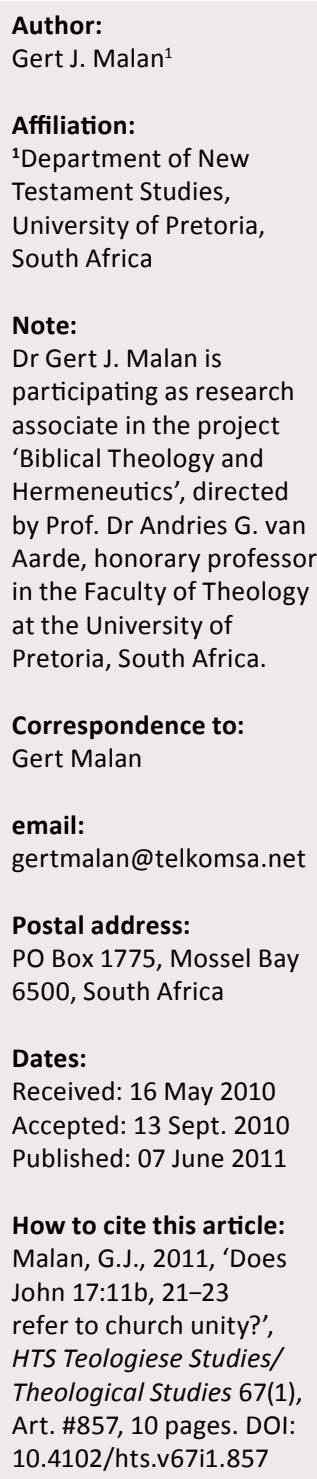

(c) 2011. The Authors. Licensee: OpenJournals Publishing. This work is licensed under the Creative Commons Attribution License.
In ecumenical circles, John 17:11b, 21-23 has been understood as Jesus' prayer for church unity, be it confessional or structural. This article questioned such readings and conclusions from historical, literary and sosio-cultural viewpoints. The Fourth Gospel's language is identified as 'antilanguage' typical of an 'antisociety', like that of the Hermetic, Mandean and Qumran sects. Such a society is a separate entity within society at large, but opposes it. Read as a text of an antisociety, John 17:11b, 21-23 legitimises the unity of the separatist Johannine community, which could have comprised several such communities. This community opposed the Judean religion, Gnosticism, the followers of John the Baptist and three major groups in early Christianity. As text from the canon, this Johannine text legitimates tolerance of diversity rather than the confessional or structural unity of the church.

\section{Church unity or unity within the Johannine community: A three-pronged approach from the 'new current'}

John 17:11b, 21-23 has generally been interpreted as a prayer of Jesus for unity within the disciple group and therefore, for church unity, be it confessional or structural. This article questioned such an interpretation and its general acceptance.

The research method for this article comprises of a three-pronged approach and thus constitutes a pluralism of methods. A socio-cultural viewpoint on the language type found in the Fourth Gospel is combined with literary perspectives and historical reasoning. Such an approach is in line with the emerging 'new current' of research on the Fourth Gospel, resulting from the influx of interdisciplinary approaches into biblical scholarship, characterised by methodological diversity (Thatcher 2006:1, 24-26).

Particularly, one characteristic of the 'new current' can be found in this research, namely a certain 'impertinence'. By this is meant the insistence that it may be worth asking other questions than those asked previously, questions which the older presuppositions might have ruled out (Culpepper 2006:209-210). In this article, the question is asked whether John 17.11b, 21-23 ever referred to church unity, as is generally accepted.

The social-scientific, literary and historical prongs of the approach found in this article is evident of the development that took place within the 'new current' in Johannine studies. Scholars of the 'new current' turned their attention to reconstructing the history of the community that preserved and shaped the Johannine tradition. Historical research soon shifted from the history of the Johannine community to the social-scientific study of the context of the Fourth Gospel (Culpepper 2006:202). Methodological innovations appeared quickly, as soon as narrative-critical perspectives were introduced. The almost exclusive dominance of historical criticism in J.A.T. Robinson's day has given way to two lines of inquiry, historical and literary, both of which have become increasingly diverse and eclectic.

The methodological unity of what Robinson (1959:338-350) called the 'New Look', has collapsed. Rival camps developed, each advocating certain concerns and methods or approaches to the text. Culpepper reiterates the importance of historical inquiry:

Regardless of how productive work in other areas may be, Johannine scholarship cannot overlook the reality that the Gospel of John was written in particular historical circumstances about a historical figure and that it is one of the early church's most important theological documents. History and theology will therefore always be vital areas for Johannine scholarship.

(Culpepper 2006:204-205)

This article accepts the vital importance of historical inquiry and, in this regard, reasons from Rudolf Bultmann (1971), C.H. Dodd (1980) and Burton Mack's (1996) understanding of the origins of the Fourth Gospel. The argument develops from Malina and Rohrbauhg's (1998) social-scientific understanding of the specific type of language found in the Fourth Gospel and is supported by insights from Berger and Luckmann's (1975) work in the field of sociology of 
knowledge. In this way, a probable historical setting for the text is sought. To this is added a literary approach, asking questions about the genre of the macro and micro text.

On the other hand, this article does concur with Culpepper's uneasiness with a certain aspect of the 'new current' of research, namely when it becomes apparent that the interpretation of the Gospel of John is not the real agenda, but the concerns that arise from the interpreter's social location. Such interpretations raise the spectre of sheer subjectivity (Culpepper 2006:208).

It is accepted in this article that different issues require different methods or approaches to the text. At the same time, the three-pronged approach is hoped to result in conclusions that are viewed as having acceptable objectivity and validity. In order to further this goal, a short discussion on the history of Johannine research before the 'new current', as described previously, follows.

\section{Before the 'new current': 'Old Look' and 'New Look'}

Research conducted on the Fourth Gospel during the past five decades (the so-called 'new current') has developed strikingly different from the 'New Look' research that followed the historical critical approach (to which Robinson [1959] referred as 'Old Look') of the previous half century. Reaction to the results of the historical critical research (referred to as 'the old critical orthodoxy' by Robinson [1959]) led to a questioning of its presuppositions. The key presupposition, that the Fourth Gospel was dependant on sources, was criticised by a fair amount of scholars, mostly from outside Germany or German critics of Bultmann (Culpepper 2006:200-201). The Johannine tradition was thus viewed as an independent trajectory of Jesus material. Since Robinson's essay and contrary to his prediction, the 'new current' research of the past half-century showed marked renewal of interest in the possibility that the Fourth Gospel was dependant on sources (Thatcher 2006:9-11).

Because the Johannine tradition was viewed as an independent trajectory of Jesus material by 'New Look' scholars, the Fourth Gospel was rated by them as a potential primary source of information about Jesus. Contrary to the 'Old Look' historical-critical approach's perspective that the Fourth Gospel was written post 70 CE outside of Palestine, the 'New Look' opted for a pre 70 CE. Palestinian origin. The previous 'Old Look' consensus, that the author of the Fourth Gospel was not an associate of Jesus, was reversed. He was now accepted as an associate of Jesus, but to the 'New Look', his specific identity was not an issue. Rejecting the previous critical consensus that the theology of the Fourth Gospel reflected late 1st century beliefs, its theology was now seen as both early primitive theology, as well as containing later developed ideas. The implication was that authorship could be attributed to more than one person or even a community (Thatcher 2006:9-11).
The 'New Look' approach drew radically different conclusions than the 'Old Look' historical-critical approach did about the Fourth Gospel. For example, Robinson, as pinnacle of this movement, accepted the priority of the Fourth Gospel and found no reason to doubt that the Johannine tradition originated with a disciple of Jesus, perhaps even the apostle John (Thatcher 2006:9-10).

Since J.A.T. Robinson's essay on the so-called 'New Look' on the Fourth Gospel (Robinson 1959), another 'new look' has emerged, namely the 'New Current', as described at first. The Gospel of John is no longer viewed as primary source next to the Synoptics and even Q, but it is regarded as a secondary source, as it has heavily reworked the tradition (Dunn 2003:165-167).

\section{Weighing different approaches}

The way any text is read influences the way it is understood. A text can be read at face value, not considering the historical and socio-cultural context, leaving the reader to decide on its meaning. A text can also be understood as a literary work, using the devices of literary criticism to study the possible nuances of meaning the text has to offer, but still at face value. Or one can add to this approach a study of the context in which the text originated, taking historical and sociocultural influences into consideration. These approaches to the text have a decisive influence on the conclusions made from the text. This is also the case when reading the Gospel of John and John 17.

\section{The Gospel of John at face value John as eyewitness}

When read at face value, the Gospel bearing the name 'John' could be viewed as written by the 'beloved disciple' (Jn 13:23) (Reinhartz 2001:22), the unnamed of the first two disciples (Jn $1: 35,40)$ as implied author. The inference drawn from a face value reading (Hendriksen 1976:4), is that the author was not only an eyewitness (1:14b, 18:15-27, 19:35, 20:30, 21:23-25), but even that no one knew Jesus better than he did and what he wrote is historically true. Such a reading assumes that the apostolic author knew the facts because he was present at the crucial points of Jesus' life and death:

- the beginning of Jesus' ministry $(1: 35,40)$

- the seven wondrous signs (2:1-12, 4:46-54, 5:1-9, 6:1-14, 6:16-21, 9:1-38, 11:1-44)

- the Last Supper (13:1-38)

- final conversations (13:31-16:33)

- Jesus' last prayer (17:1-26)

- Jesus' arrest (18:1-14)

- Jesus' crucifixion (19:17-27)

- Jesus' death (19:28-35).

- the empty tomb $(20: 1-8)$

- Jesus' resurrection appearances (20:19-23, 20:26-29, 21:23-25).

With a face value reading, the complex issue of authorship is often approached in an overly simplistic, un-academic and uncritical way. 


\section{John 17 at face value}

Is John 17 a prayer of the historical Jesus? This preliminary question is answered in the affirmative when this chapter is read at face value, although other early options could be considered. For example, Theodore of Mopsuestia regarded the text as a prophesy by Jesus, whilst John Chrysostom interpreted it as a hortatory monologue by Jesus (so Wendland 1992:67).

The text can also be studied using communication theory:

John 17 presents a rather clearly defined 'communication event' in that it delineates the speaker (Jesus), an addressee (his heavenly Father), a group of witnesses who hear what is said (Christ's disciples), a setting (an evening meal before the Passover, cf. 13:1-2) and a message - in this case an overtly demarcated verbal text (i.e. by the corresponding 'inclusive' marginal comments in 17:1 and 18:1).

(Wendland 1992:64)

Another possibility is to view John $13-17$ as liturgical text, for the church celebrating the triumph of God's love shown in Christ. John 17 is then understood as a prayer providing a liturgical inclusio. In this sense, John 13-17 need not be viewed as historical fact, but as theological commentary on the meaning of the incarnation and the Eucharist, as well as an introduction to the passion. Nevertheless, it can also be understood as both historical fact and theological commentary (Suggit 1992).

The study of the structure of John 17 may assist one's understanding of the basic development of the train of thought. Even when doing a colon analysis, revealing the obvious time consuming, well planned rhetorical structure of John 17, some nevertheless approach the text as the historical Jesus' spontaneous Farewell Prayer (Black 1988; Boyle 1975; Malatesta 1971; Suggit 1992; Tolmie 1993; Wendland 1992; Wong 2006).

John 17 can be interpreted as a prayer that contains the Lord's 'last will' (Coetzee 2006:165). This is in line with what Wendland (1992:67) calls the didactic purpose of the prayer. Christ reviews the principal themes of his gospel message for the benefit of his faithful few in this poetic and memorable prayer.

\section{John $\mathbf{1 7}$ as prayer for unity of faith}

When John 17 is read as a prayer of the historical Jesus and focusing on the petitions for unity $(17: 11 b, 21-23)$, the following conclusions are possible: The first petition for unity refers to unity amongst the disciples (17:11b). The second petition (17:21-23) refers to the unity of the church of the future. This unity can be interpreted differently. One can deduce from 17:21-23 that the unity of the 'future church' can be likened to the unity between the Father and the Son, that is to say, an invisible unity, a unity of purpose (Dreyer 1970:15). Applied to the 'future church' the unity is one of confession and the proclamation of Jesus as Saviour. It is a unity that must be cherished, as it can be broken when moving away from the unifying confession. Understood in this way, Jesus prays, not for structural unity amongst the many churches across the world, but for their unity of faith (Appold 1978; Black 1988; Dreyer 1970; Gruenler 1989; Hesselgrave 2000).

In practical terms, such a face value reading of John 17:11b, 21-23 motivates fellowship and cooperation, which should be actively sought, between churches of the same confession. Central and peripheral aspects of the confession should be identified. Compliance with the central doctrines is required, whilst different nuances can be tolerated for non-essential doctrines (De Waard 1992: 564-565).

\section{John 17 as prayer for structural unity}

If John 17 is read as Jesus' 'last will', an essential part of this 'last will' is the visible unity of the church, which implies unity in confession. Understood as such, the church has a calling to fulfill this task in obedience and in the surety of the will of Jesus Christ. At stake are the salvation of many people and the future survival of the church (Coetzee 2006:165).

The purpose of Jesus' prayer and mission is then understood as providing one undivided nation for his Father. This unity cannot be taken for granted. Jesus' followers must work towards this end. It should be a visible unity within the harsh realities of the world. From this face value reading of John $17: 11 b, 21-23$ visible church unity is regarded as of the utmost importance and becomes the mark of the true church. Structural unity should facilitate the unity of confession and love within the church (Cadier 1956:175-176; Du Preez 1986:5).

The visible structural unity of the church becomes the prerequisite for the faith of the world and even for the believers themselves, as seeing is believing (Botman 1997:134; Burger 1984:123). Until structural unity realises, historical disunity is viewed as a tragic road (Jacobs 2007:7). Although John 17:11b, 21-23 is in the form of a prayer and not a commandment for unity, believers should confess the sin of disunity, follow the Lord in praying for unity (Burger 1984:125) and then take action to realise it (Jacobs 2007:7).

Not understanding the text in this way is judged in strong language: as cheap explanations ignoring an essential issue and thereby placing the image of God and the faith of the church in jeopardy. Taking the unity of the church lightly in this way shows lack of love for the world and disdain for God (Burger 1984:123).

\section{The Fourth Gospel read in its literary, historical and socio-cultural context}

Three interdependent approaches are followed to uncover the context for understanding this text. Historical research is concerned with identifying the probable historical setting in which the document originated by constructing hypotheses based on information in the text. Literary analysis studies the narrative structure of the text and its function. Understanding this dynamic assists the historical enquiry about the origins 
of the document (Kysar 1984:11). Social-scientific criticism complements these other modes of critical analysis, all designed to analyse specific features of the biblical texts. It does so by investigating how societies were organised and how they functioned (Elliott 1993:7, 13). Sociology of knowledge, as part of the social-scientific enquiry, studies the 'worlds' of texts as human constructions by communities or narrators. These constructed worlds are comprised of the same kinds of social facts as so-called real worlds, namely symbolic forms (symbolic universes) and social arrangements (social universes) (Peterson 1985:ix-x). The Fourth Gospel's narrative world can thus be studied like any other world. As seen through a transparency, several aspects about the symbolic and social universes of the Johannine group will become apparent when they are viewed through the Gospel's narrative world.

\section{Genre of the Fourth Gospel}

Is the genre of the Fourth Gospel ancient historiography by an eyewitness? Until the middle of the 20th century it was customary to answer this question as if it was a question about authorship. Some scholars answered the question positively because they advocated for an apostolic author. This implied that the Fourth Gospel was a historically factual account, which posed the problem of apparent conflicts with the synoptic traditions. Other scholars preferred an un-apostolic author that gave the Gospel the character of theology rather than history and opened the possibility of Hellenistic influences and dependency on the Synoptic Gospels (Smalley 1983:11).

Since then the focus has shifted. Robinson (1959:338-350) illustrated that this 'old look' at the Fourth Gospel drives a wedge between the author and his tradition. He advocated for a 'new look', focusing on the nature and origin of the Johannine tradition, letting the issue of authorship recede into the background.

Eventually the original maxim of biblical criticism, that the Biblical texts should be read like any other literature, was applied to the Gospels. The literary aspects of the Gospel, such as plot, characters, irony, misunderstanding and symbolism became the focus. From a literary point of view the text is viewed as a narrative, as John's story about Jesus. Literary analysis is not interested in the question of historicity, the historical Jesus, the historical author or the factual truth of events and claims in the story. What is new and different is a commitment to understanding the narrative world of the Gospel on its own terms (Smith 1986:94-95). It is concerned only with what the author says about Jesus and how the plot unfolds (Kysar 1984). Concerning the relationship with the synoptic Gospels, both similarities and differences should be noted but not exaggerated. The author of the Fourth Gospel, just like the authors of the Synoptic Gospels, used sources and reshaped material in accordance to his theological outlook (Smalley 1983:29).

More recently, the gospel genre was likened to the ancient genre of 'bios' of important people (Burridge 1998, Dunn
2003:185-186). The 'bios' genre must not be understood in terms of the modern day biography. It also differs from present day historiography and is more like narrative:

They are more like a piece of stained glass through which we can catch the occasional glimpse of what is behind them and in which we sometimes mistake our own reflection from in front of them, but upon which the main picture has been assembled using all the different colours of literary skill - and it is a portrait of a person. The historical, literary and biographical methods combine to show us that the Gospels are nothing less than Christology in narrative form, the story of Jesus.

(Burridge 1998:124)

The Fourth Gospel is neither an eyewitness account, nor historiography reporting the factually correct eyewitness statements of others. It tells a story of Jesus in its own way, using and moulding several traditions in the process. The unfolding of the story reveals how 'John' as individual 'bios' author (Burridge 1998:125-130) and consequently, his community, understood Jesus and how they believed Jesus to be. It is the revelation of the 'Johannine' Jesus and accordingly, the Jesus of their faith.

Referring to 'the Johannine community' (singular) does not exclude the probability that there could have been several such communities within the early Christian movement. The discussion that follows on the Hermetic communities suggests such a possibility. Bauckham (1998b:10-13, 17, 3044 ) rightly criticised the previously unquestioned assumption that the gospels were written only to specific congregations and not for the Christian movement in general. He also stated that the flow of information between congregations did not exclude diversity, strife and rivalry. As will be shown, my contention is that the language of the Fourth Gospel suggests that there was a Johannine sect (which could include several congregations, even spread geographically over a wide area), which separated itself from other religions as well as from the main Christian groups. This evidence refutes Bauckham's (1998b) claim that:

none of this evidence for conflict and disagreement suggests that any version of Christianity formed a homogenous little enclave of churches and renouncing any interest or involvement with the wider Christian movement.

(Bauckham 1998b:43)

This does not mean that the Fourth Gospel was written solely for the Johannine group. As will be shown in the discussion that follows, certain language strategies in the Fourth Gospel were specifically designed for attracting and resocialising new members. As Zimmermann (2006:42-43) sees it, the Johannine imagery works toward an inclusion of the recipient and can be interpreted as directive to the recipients. The implication is that the Fourth Gospel must have had a wider audience within the Christian movement already acquainted with the Gospel of Mark (Bauckham 1998c:147-150, 169-171) and even outside of the Christian movement (Barton 1998:184-186). Such outsiders were, when reading the Fourth Gospel, subtly invited to join, specifically, the Johannine group. For such readers, as well as members of the group, the gospel as 'bios' functions as social legitimation of the Johannine theology and group (Burridge 1998:120-122, 135-137). 


\section{Genre of John 17}

Structural analysis of John 17 hints that this is not a verbatim account of the spontaneous prayer by the historical Jesus, witnessed by his disciples. Several themes from the Gospel and especially from the discourse in John 13-17, are skillfully and artfully revisited (Black 1988, Boyle 1975, Malatesta 1971, Suggit 1991, Tolmie 1993, Wendland 1992, Wong 2006:374-392). The structure reveals a discourse with an intricate pattern that must have needed a lot of time and careful planning to construct. It represents the climax of the discourse that started in John 13:31 and prepares readers for the narrative of Jesus' arrest. Although in form it is discourse, in style it comes closer to poetry. In the form of a farewell prayer, this collage of Johannine themes communicates powerfully (Kysar 1984:73-74).

\section{Historical and socio-cultural context of the Fourth Gospel}

Historical-critical scholars date the Fourth Gospel post 70 CE (Thatcher 2006:8), some (Mack 1996:176) even as late as the 90s CE. This was a time when the first flush of excitement had subsided in the Jesus movements and Christian congregations. The imagined kingdom of God had been postponed or displaced, projected onto locations at the far ends of the human imagination, for example in heaven above, in the deep structure of the universe, at the creation of the world or at the eschaton (Mack 1996:176).

It is accepted that if the Fourth Gospel is to be used as a source for the historical Jesus, it would have to be as a secondary source, as the traditions used have been heavily worked upon, for example the 'farewell discources' can be viewed as meditations on significant words and deeds of Jesus (Dunn 2003:167).

The situation of the Johannine group that is reflected in the Fourth Gospel is one of conflict with Judaism. The term 'Judaism' describes the system of religion and way of life that maintained the distinctive Jewish national and religious identity vigorously resisting the assimilating and syncretistic influences of wider Hellenism (Dunn 2003:262). The Johannine community had already been excluded from the synagogue association $(9: 22 ; 16: 1-3)$. The author felt the estrangement of his group from Judaism to be so great that Jesus already appears as no longer a member of the Jewish people or its religion in his account. Jesus speaks to the Jews of their law as 'your law' as if he were a non-Jew (Bultmann 1955:5). Even a purely narrative approach, reading from different perspectives, cannot ignore the anti-Judaism of the Fourth Gospel (Reinhartz 2001:160-167).

The discourses express a dualistic view that coincides with the dualism of Gnosticism, especially that of the Mandaean sect. The figure of Jesus is portrayed in the forms offered by the Gnostic Redeemer-myth (8:17; 10:34 cf. 7:19, 22) (Bultmann 1955:1-12). In Gnostic terms, a pointed anti-Gnostic theology is expressed, as the Fourth Gospel knows no cosmic or anthropological dualism. In the place of it steps a dualism of decision, namely of faith or unbelief in the Redeemer that has become flesh (Bultmann 1971:7-9). The use of Gnostic language may indicate that the Johannine group lived in a society that was familiar with Gnostic terms and ideas, to which the group itself is ideologically directly opposed.

The prologue of the Fourth Gospel places readers in the presence of God before the world was made; watching as his powerful logos begins to move and create life and light that streak through the universe, changing darkness into day. It is not long before the logos is identified as Jesus. This is a totally different world from the ones projected by the Synoptic Gospels. Readers are placed in the presence of a cosmic power that pulsates throughout the world, making all of time and space eternally present around us. It is the world of the cosmic Christ. As everyone who was influenced by Greek thought, early Christians thought of their world as an organism (cosmos), a universe pulsating with powers that both threatened to break it apart and pulled it back together. Critical questions were how the cosmos was structured and how the cosmic powers were imagined to function (Mack 1996:75-176).

The Fourth Gospel answers these questions, not by telling about Jesus' redemptive death or an apocalyptic confrontation, but of his appearance in this world and his return to his heavenly abode. Couched between the descent of the logos and Jesus' return to the Father, the miracle stories and the dialogues they spawn are simply seven chances for the Johannine Christians to watch and enjoy the collision of the world of enlightenment and the world of darkness, a collision they experienced every day. The Johannine community cultivated the image of the cosmic Christ. His words become invitations to personal enlightenment (Mack 1996:183).

This enlightenment was supposed to make sense of life within the harsh realities of the real world the Johannine community lived in. It was a pre-industrial period of advanced agrarian societies that characterised the 1st century Mediterranean region. The text of the Gospel was written in order to have some social effect. To have been understood, the wording of the Gospel had to refer to a common social system. Sociolinguistically spoken, the meanings that languages express are not in the wording level, but realise their meanings from a specific social system and the way people speak in everyday situations. Members of various societies can predict the types of meaning that might be exchanged from the scenarios in which speaking takes place (Malina \& Rohrbaugh 1989:3-4). The question is: what situation and what set of concerns might adequately explain the scenes presented in the Fourth Gospel?

\section{What the language of the Fourth Gospel tells us}

In order to answer this question, one needs to investigate the kind of language used in the text. The Fourth Gospel is a religious text that uses symbolic language with a high frequency. Symbolic language provides the maximum 
detachment from the here and now. It constructs immense symbolic edifices that tower over the reality of everyday life like presences from another world (Berger \& Luckmann 1975:55). These edifices are called symbolic universes. They legitimate the social world by means of symbolic totalities. All sectors of a society are integrated in an all-embracing frame of reference. It is called a universe because all human experience can be conceived as taking place within it. As such, the symbolic universe becomes the matrix of all socially objectivated and subjectively real meanings, notably also of those marginal experiences not part of everyday life, such as dreams and death (Berger \& Luckmann 1975:110-114, 119).

The way in which language is used reveals how the symbolic universe legitimates and maintains a society. A special feature of the Fourth Gospel is 'relexicalisation', which refers to the practice of using new words for some reality that is not ordinarily referred to with those words. To call money 'bread' or a pistol a 'piece' are examples of relexicalisation. The implicit principle behind relexicalisation seems to be same grammar but different vocabulary, although only in certain areas. Relexicalisation points to items and objects affecting areas of central concern to the group. Relexicalisations in the Fourth Gospel derive from interests and activities of the Johannine community. This concern is for instance articulated as 'that you may continue to believe that Jesus is the Messiah, the Son of God, and that through believing you may have life in his name' (John 20:31) (Malina \& Rohrbaugh 1989:4-5). This is exemplary of the symbolic universe legitimating and maintaining the alternate social reality of the Johannine group.

Another feature of the language used in the Fourth Gospel is overlexicalisation. Many different words are used for the central areas of concern. Examples are the contrast between spirit, above, life, light, not of the or this world, freedom, truth, love and their opposites flesh, below, death, darkness, the or this world, slavery, lie, hate. These two sets of words, indicative of the so-called Johannine dualism (Bultmann 1955:15-32), are variants used to describe contrasting spheres of existence, opposing modes of living and being. Similarly, believing into Jesus, following him, abiding in him, loving him, keeping his word, receiving him, having him or seeing him are used with almost no appreciable difference in meaning (Malina \& Rohrbaugh 1989:5). These opposite sets of terms are part and parcel of 'nihilation', a mechanism of universe maintenance. It is used when the groups' symbolic universe and therefore the survival of the group as social entity, is under threat from an alternative symbolic universe of an opposing group. Nihilation involves the attempt to account for all deviant conceptions of reality in terms and concepts belonging to the groups' own universe (Berger \& Luckmann 1975:126, 133). By directly contrasting these concepts, the alternative symbolic and social universes are confronted in a forceful way.

The language of the Fourth Gospel focuses on the interpersonal and textual modes of language, rather than on the ideational (factual). John's well-known pattern of ambiguity, misunderstanding and clarification, his verbal display and wordplays and his penchant for irony are instances of overlexicalisation based on the textual function of language. The interpersonal dimension of language is especially important in John. Overlexicalisation, based on this function, is indicated by the set of words that has the same denotation but quite a different connotation based on the attitude and commitment the set of words entails in an interpersonal context. For instance, all Jesus' 'I am' statements have the same denotation (e.g. bread, light, door, life, way, vine) in referring to real-world objects, but in an interpersonal relationship to Jesus they denote activities of discipleship (e.g. to believe, come, abide, follow, love, keep words). This orientation towards the interpersonal and textual modes of language accounts for the way in which social values are fore grounded, highlighted and understood in John. It also indicates that John and his group looked for the implementation of new values, not new structures, in place of old ones. The consistent relexicalisation, overlexicalisation and focus on the interpersonal and modal aspect of language points to 'antilanguage' (Malina \& Rohrbaugh 1989:6-7). Dunn (2003:183) refers to such language in the 1st century CE Christian movements as 'boundary forming' and 'insider's language'.

\section{The Johannine community as an antisociety}

'Antilanguage' is the language of an 'antisociety' that is set up within another society as a conscious alternative to it. It is a mode of resistance, which may take the form of passive symbiosis or active hostility, or even destruction. The language of members expresses their social experience and self-understanding in opposition to society. Just as antisociety opposes society, antilanguage opposes the language of society (Malina \& Rohrbaugh 1989:7-9).

Applied to the Fourth Gospel, the antilanguage used reflects the alternate reality that the Johannine community has themselves set up in opposition to its opponents. This does not imply that they were expelled from society because of their beliefs and attitudes. Rather, the Johannine group set up an alternate reality in opposition to their opponents, notably 'this world' and 'the Jews or Judeans'. In the eyes of their opponents, they were either on the margins of prevailing norms or laws or transgressed these. On the margins, they are not illegal, but are in a space that custom or law does not, or cannot, cover. Or, as lawbreakers, they subsist in an 'outside' hollowed within society. Like all antilanguage, John's is consciously used for strategic purposes, defensively to maintain a particular social reality or offensively for resistance and protest (Malina \& Rohrbaugh 1989:9). The Johannine imagery is a good example. It is directed towards the inclusion of any readers, inviting them to accept the Johannine theology. At the same time, the imagery is open and blurry and opens up communication about it within the Johannine society. Their interpretation must be spoken, their substance must be wrestled with and their truth must be fought for as was true within the Johannine community (Zimmermann 2006:43) in opposition to other groups. As such, the imagery is directed toward inclusion of new 
members whilst also binding all members through dialogue about their meaning.

In concrete terms, the larger groups, which were opposed by the Johannine group, are 'the (this) world' and 'the Jews or Judeans' and Gnosticism. These groups adamantly refuse to believe in Jesus as Israel's Messiah (Bultmann 1955, 1971; Malina \& Rohrbaugh 1989:10). Four other competing groups can also be identified (Brown 1979:168-169):

- the adherents of John the Baptist, who do as yet not believe in Jesus because they misunderstand him

- 'crypto Christians', who were Christian Jews who had remained within the synagogues by refusing to admit publicly that they believed in Jesus

- 'Jewish Christians' who had left the synagogues but whose faith in Jesus was inadequate by Johannine standards because they did not accept Jesus' divinity

- 'Christians of the apostolic churches' who were mixed communities of Jews and Gentiles that were separate from the synagogues and regarded themselves as heirs of the Christianity of Peter and the Twelve, but who did not fully understand Jesus or the teaching function of the Paraclete as the Johannine group did.

In John's antilanguage, we find the expression of an alternative society to 1st century Mediterranean Hellenism in general and of its Israelite version in particular. They were not the only antisociety. Other alternative societies with whom the Johannine community is frequently compared, especially in terms of language, are separatist Gnostic communities such as the Hermetic (Bultmann 1971; Dodd 1980) and Mandaean societies (Bultmann 1971; Dodd 1980) and the Qumran sect (Smalley 1978).

\section{The Hermetic communities}

The thought world of the Hermetic societies is represented by the Corpus Hermeticum. The fusion of Platonism and Stoicism compared with religious influences from Zoroastrianism, Oriental sun-worship and Hebrew religion to form the nonChristian Hellenistic Gnosticism of the Hermetic tradition (Bultmann 1971; Dodd 1980:10-12).

The initial members of the Hermetic communities were Egyptians, who offered their own version of the religion of gnosis, which others propounded in a manner more appropriate to their own national backgrounds, notably Hebrew, Syrian, or Mesopotamian. Pagan monks and hermits gathered together in the deserts of Egypt and other lands. They gave strict attention to cleanliness, silence during meals, seclusion and meditative piety. It would seem that the Hermeticists were recluses of this kind. Unlike the Gnostics, who were mostly living secular lives in cities, the Hermeticists followed a lifestyle similar to the kind Josephus attributes to the Essenes (Hoeller 1996).

Dodd (1980:12-53) discusses, amongst the differences in basic ideas, the striking similarities between the Fourth Gospel and the Hermetic writings and concludes that as a whole, the Corpus Hermeticum represent a kind of religious thought akin to certain aspects found in the Fourth Gospel. Although most of these writings are probably later in date than the Fourth Gospel, they represent a kind of religious thought that can be traced to a much earlier period. Bultmann (1971:27-28) speaks of a 'pre-Gnostic' origin of the Gnostic myth, of which traces can be found in the pantheistic parts of the Corpus Hermeticum. He interprets the appearance of parallel forms of the basic ideas in both religious-philosophical literature of Hellenism from the 1st century onwards and in the Christian Gnostic sources as proof that the basic conception of the Gnostic viewpoint reaches back to the pre-Christian era. At least it is probable that the Corpus Hermeticum and the Fourth Gospel had a shared thought-world that both led their communities of followers to develop as separatist movements.

\section{The Mandaean communities}

Small communities of the Mandean sect still live in Iraq and Iran. The Mandean literature has undergone considerable reappraisal since the discovery of the Coptic Gnostic texts from Nag Hammadi in 1947. Their writings, principally the Ginza (Treasure) and the Book of John (both collections of tractates), represent a Gnostic kind of dualism. As a collection, their documents cannot be dated much before 700 $\mathrm{CE}$, because it contains references to Mohammed and the Islamic faith. No doubt some of their writings come from a much earlier period (Smalley 1978:45).

The Johannine version of Christ as the Redeemer was probably influenced by a pre-Christian Mandean myth, at the heart of which lay the Iranian redemption mystery. According to this theory, proposed by Reitzenstein and Bultmann, John the Baptist was responsible for the formation of the Mandean myth and ritual and the Mandeans themselves were successors of the Baptist sect allegedly referred to in Acts 18:24-19:7 (Dodd 1980; Smalley 1978; see also Bultmann 1971 on the Mandean background to the 'Logos' term). Although the theory may seem like a masterpiece of ingenuity that depend on arbitrary assumptions (so Dodd 1980:121), the renowned Mandean scholar Lady E.S. Drower has reasserted the thesis that Mandaism derives from a pre-Christian period (Smalley 1978:47). What the Mandean and Johannine communities also have in common is that their dualistic outlook gave them the character of sects or alternative religious communities on the pattern of antisocieties.

\section{The Qumran community}

Some priestly families reacted strongly against the Hasmonean kings assuming the role of high priest and their taking control of the temple in Jerusalem. They withdrew to a barren shelf above the Dead Sea and established a community at Qumran (Mack 1995:22-23 ). The discovery of their documents in 1947 made it plain that even before the Christian era began a literary setting existed in Qumran that combined Jewish, Greek and 'pre-Gnostic' religious ideas in a way that once was thought to be unique to John. The links between the Dead Sea Scrolls and the Fourth Gospel are numerous. There are obvious literary parallels with 
many Qumran documents, particularly with the 'Manual of Discipline' (or 'Community Rule'). Points of contact exist not only in shared terminology and recurring themes. Contact existed at a deeper level still. Both the Essenetype community and the Johannine society had 'modified dualism' as an outlook on the world (Smalley 1978:30-33). Such an outlook forms a type of symbolic universe conducive to an antisociety's separatist social universe.

\section{The Johannine community}

The previously mentioned groups functioned as alternative societies to both non-believers and the large communities of faith from which they separated. To an extent, they still made use of the common symbolic and social frames of reference. Their literature was the stories that held them together and legitimated their beliefs, values and practices and thus reinforced their character as alternative societies in opposition to society at large.

This is also true of the Johannine community. Both the Jewish or Judean and Johannine society had the same overarching system of meaning, just as both were part and parcel of the same overarching social system. Yet, they stand in opposition to and in tension with one another (see also Reinhartz 2001:81, 84-87). This is an important point, because an antisociety makes no sense without the society to which it stands opposed. The Johannine group and the story that held it together make sense only in the Jewish or Judean society in which it originated. When removed from the society in which it made sense, the Fourth Gospel quickly loses its original meaning (Malina \& Rohrbaugh 1989:10).

What role would the Fourth Gospel play within the Johannine society? As the historical and literary approach of this article has shown, the Fourth Gospel does not contain history, but narrative couched in symbolic or mythological language. Mythology is historically the most archaic form of universemaintenance, as it represents the oldest form of legitimation by positing the ongoing penetration of the world of everyday experience by sacred forces. Such a conception of reality entails a high degree of continuity between social and cosmic order and between all their legitimations. All reality appears as made of the same cloth (Berger \& Luckmann 1975:127-128)

The way in which the mythological language is used as antilanguage in the Fourth Gospel makes the legitimation even more powerful. Antilanguages are generally replications of social forms based on highly distinctive values. These values are clearly set apart from those of the society it opposes. Antilanguage is the bearer of an alternative social reality that runs counter to the social reality of society at large. This accentuates the importance of resocialising new members and maintaining group solidarity. The Fourth Gospel as foundation story (Dunn 2003:186) would have served both objectives in the face of pressure from the wider society. It would provide the alternative ideological and emotional anchorage for demonstrations of mutual care and concern. The result would be strong affective identification established for newcomers as well as those on the fringes ready to swing out. The genre most appropriate to this end is conversation and its modes of reciprocity. The Fourth Gospel abounds with instances of conversations with Jesus that serves the function of resocialisation (Malina \& Rohrbaugh 1989:11).

Such an alternative reality has several characteristics. New core values are emphasised, together with an attempt to create standards and structures to implement those values. This is combined with a preoccupation with social boundaries, social definition and the defence of identity, usually by the repeated and varied articulation of the new reality now so clearly perceived. Importantly, the counter reality of the Johannine community implies a special conception of information and knowledge of which Jesus, eminently, is the revealer (Malina \& Rohrbaugh 1989:12).

'Internalisation' (Berger \& Luckmann 1975:150, 157-159) (called 'faith' in the Fourth Gospel) is the highly emotional process by which new members accept the world in which the rest of the Johannine community already lives. But internalisation is not a matter for once and for all, it is never total and never finished. Further internalisations are needed to reinforce the primary process. These entail a legitimating apparatus such as rituals. From the contents of the Fourth Gospel, one can deduce that the Johannine group most probably met for meals, washed one another's feet, prayed together and sang hymns of praise to the logos, rather than practicing the rituals of baptism and Holy Communion (Mack 1995:183). Material symbols like images and allegories (Berger \& Luckmann 1975:158-159), are frequently found in the symbolic language of the Fourth Gospel, further assist the ongoing process of internalisation.

\section{Antisociety as very high-context society}

In order to avoid ethnocentric and anachronistic readings of the text, one should take note that the societies in which the New Testament texts originated were 'high-context' societies. People in such societies presume a broadly shared, wellunderstood, or 'high' knowledge of the context of everything that is referred to in conversation or in writing. There is no need to explain it. The texts of such societies are therefore sketchy and impressionistic documents, leaving much to the reader's or hearer's imagination. Often information is encoded in widely known symbolic or stereotypical statements. The reader is required to fill in the large gaps in the 'unwritten' portions. All readers are expected to know the social context and therefore, to understand the references in question (Malina 2001:2-3).

The original readers, or hearers, of the Fourth Gospel were assumed to be primarily members of the Johannine alternate society. This means that they were expected to have a high knowledge of that peculiar context and accordingly, the text offers little in the way of explanation. In this case an alternate society such as the Johannine group was an even higher context society than the society at large (Malina \& Rohrbaugh 1989:16). 
It is important to notice the difference with today's societies in the developed world that are 'low context'. A 'low' knowledge of the context is assumed, thus highly specific and detailed documents are produced that leave little for the reader to fill in or supply. The obvious problem this creates when reading the Biblical texts, is that Biblical writings are regarded as 'low context' documents. This means that the author is wrongly assumed to have provided all of the contextual information needed to understand it (Malina 2001:3-5).

\section{Recontextualising the Fourth Gospel}

As soon as the Johannine society disappeared, the Fourth Gospel was decontextualised when read by ordinary Mediterraneans. John became 'the Theologian' with all sorts of information about the nature of Jesus simply unknown to any other New Testament writers. Decontextualisation reaches its peak when the text is read ahistorically in a nonMediterranean modern culture of the developed world. Recontextualisation takes place as a form of modernisation, which is a profoundly social act. The problem is that modern readers in the developed world cannot complete the text of the 'high-context' society as the author supposed his readers would. As a rule, nonunderstanding or, at best, misunderstanding will take place. The examples of face value readings of the Fourth Gospel and chapter 17 reveals such recontextualisation and the subjectivity it bespeaks. To circumvent this, readers should seek access to the social system(s) available to the author's original readers. One is the social system of the eastern Mediterranean in antiquity and the other is the Johannine antisociety (Malina \& Rohrbaugh 1989:18-19).

\section{Recontextualising John 17}

It is my contention that reading John $17: 11 b, 21-23$ as a prayer of the historical Jesus for the structural, or even the confessional, unity of the church may well be a misunderstanding or an example of nonunderstanding. Such understanding is the result of a-historical reading as decontextualising and recontextualising the text. Structural unity within 'the' church was probably a non-issue, which was carried into the text as part of modernisation and recontextualisation.

This misunderstanding can be prevented by reading it as part of the narrative text of the 1st century Mediterranean Johannine antisociety. As conclusion to the farewell conversations in the form of a prayer as final conversation with God, it is a highly effective means of communicating the core value of unity to the group and recocialising new members. This argument is strengthened by the repetitive use of 'the world' as term indicating the opposing society at large. Another strategy is using the unity between Jesus and the Father as a metaphor for the unity of the group. The use of such a metaphor would have served to express the new experience and perceptions of the group and its core value of unity, as it would have been the function of the Fourth Gospel to reinforce the group's new interpretation of reality (Berger \& Luckmann 1975; Malina \& Rohrbaugh 1989:14-15). Read in this way, it becomes a prayer for the unity of the Johannine community in its opposition to Judaism, Gnosticism, the followers of John the Baptist and contemporary Christian groups.

\section{Conclusion}

It is doubtful that the early Christian communities in general and the Johannine society in particular, thought about themselves and their relationship to the various Jesus movements as a structural or even a confessional unity (Käsemann 1970; Mack 1996; Malina \& Rohrbaugh 1998:9-19). It is probably quite the contrary. This article has shown the Johannine community to be an antisociety that opposed not only Judaism and Gnosticism, but also at least three other types of early Christian groups that seemed to form the bulk of early Christianity, including followers of John the Baptist.

This implies that the prayer of John 17:11b, 20-23 should be understood as a prayer for the unity and solidarity within the Johannine antisociety in opposition to other communities of faith. It is ironic that this 'prayer', that is generally read as motivation for ecumenical unity, be it structural or confessional, was most probably used for exactly the opposite purpose: to legitimise non-confirmation of the Johannine community with opposing groups, even within the Christian fold. Understood in this way, it should be read as a plea for ecumenical diversity rather than structural, or even theological or confessional, unity.

To infer from this text that confessional and especially structural unity is an imperative or even a mark of the true church that should be actively sought, is not supported by this article.

\section{Acknowledgement}

It is an honor to contribute in this way to celebrate the academic career of Prof. Andries van Aarde. During the past 29 years I came to know him as an extraordinary person. He was and is still capable of producing a tremendous load of quality research in the field of New Testament studies, as his list of publications shows. It is only possible to deliver such a volume of excellent work when a deep-rooted motivation is present. Andries van Aarde has an immense love for God, church and theology. Because of this loyalty, there is no room for compromise in his theological research and the leadership he shows in the church. His accomplishments did not result in a sense of self-importance. He is known for his modesty and his willingness to serve. Andries van Aarde is an example of dedication, steadfastness, hard work, humility and faith that is hard to follow.

\section{References}

Appold, M., 1978, 'Christ alive! Church alive! Reflections on the prayer of Jesus in John 17', Currents in Theology and Mission 5(6), 365-373. 
Barton, S.C., 1998, 'Can we identify the Gospel Audiences?', in R. Bauckham (ed.) The Gospels for all Christians: Rethinking the Gospel audiences, pp. 173-194, Eerdmans, Grand Rapids.

Bauckham, R. (ed.), 1998a, The Gospels for all Christians: Rethinking the Gospel audiences, Eerdmans, Grand Rapids.

Bauckham, R., 1998b, 'For whom were the Gospels written?', in R. Bauckham (ed.), The Gospels for all Christians: Rethinking the Gospel audiences, pp. 9-48, Eerdmans, Grand Rapids.

Bauckham R., 1998c, 'John for readers of Mark', in R. Bauckham (ed.), The Gospels for all Christians: Rethinking the Gospel audiences, pp. 147-171, Eerdmans, Grand Rapids.

Berger P.L. \& Luckmann T., 1975, The social construction of reality, Penguin, Harmondsworth.

Black, D.A., 1988, 'On the style and significance of John 17', Criswell Theological Review 3(1), 141-159.

Botman, H.R., 1997, 'Eenheid en geloofwaardigheid (Joh. 17:21)', in C.W. Burger, B.A Müller \& D.J. Smit (reds.), Riglyne vir die prediking oor die eenheid van die kerk, pp. 129-135, Woord teen die Lig III/5, Lux Verbi, Kaapstad.

Boyle, J.L., 1975, 'The last discourse (13:31-16:33) and prayer (John 17): Some observations on their unity and development', Biblica 56(2), 210-222.

Brown, R.E., 1979, The community of the beloved disciple, Paulist, New York.

Bultmann, R.K., 1955, Theology of the New Testament, Volume Two, SCM, London.

Bultmann, R.K., 1971, The Gospel of John, Blackwell, Oxford.

Burger, C.W., 1984, 'Johannes 17:20-23', in C.W. Burger, B.A. Müller \& D.J. Smit (reds.), Riglyne vir, pp. 119-126, Woord teen die Lig 4, N.G. Kerk-Uitgewers, Kaapstad.

Burger, C.W., Müller, B.A. \& Smit, D.J. (reds.), 1984, Riglyne vir nagmaalsprediking, Woord teen die Lig 4, N.G. Kerk-Uitgewers, Kaapstad.

Burger, C.W., Müller, B.A. \& Smit, D.J. (reds.), 1997, Riglyne vir die prediking oor die eenheid van die kerk, Woord teen die Lig III/5, Lux Verbi, Kaapstad.

Burridge, R.A., 1998, 'About People, by People, for People: Gospel Genre and Audiences', in R. Bauckham (ed.), The Gospels for all Christians: Rethinking the Gospel audiences, pp. 113-145, Eerdmans, Grand Rapids.

Cadier, J., 1956, 'The unity of the church', Interpretation 11, 166-176.

Coetzee, C.F.C., 2006, 'Christian identity and church unity', In die Skriflig 40(1), 155-168.

Culpepper, R.A., 1983, Anatomy of the Fourth Gospel. A study in literary design, Fortress, Philadelphia.

Culpepper, R.A., 2006, Where will the New Currents take us?, in F. Lozada \& T. Thatcher (eds.), New currents through John: a global perspective, pp. 199-209, Thatcher (eds.), New currents through John: a global perspective, pp. 199-209,
SBL, Resources for biblical study No. 54, Society of Biblical Literature, Atlanta.

De Waard, H., 1992, 'The unity of the Church', In die Skriflig 26(4), 563-567.

Dodd, C.H., 1980, The interpretation of the Fourth Gospel, Cambridge University Press, Cambridge.

Dreyer, A.J.G., 1970, Sodat hulle een kan wees, Die Hervormer, April, p. 15.

Dunn, J.D.G., 2003, Jesus Remembered. Christianity in the making, vol. 1, Eerdmans, Grand Rapids.

Du Preez, J., 1986, 'Kerkeenheid -'n getuienis vir die wêreld. Joh. 17 van nader bekyk', Die Kerkbode, 03 September, p. 1.

Elliott, J.H., 1993, What is social-scientific criticism?, Fortress, Mineapolis.

Frey, J., Van der Watt, J.G. \& Zimmermann, R. (eds.), 2006, Imagery in the Gospel of John, Wissenschaftliche Untersuchuningen zum Neuen Testament 200, Mohr Siebeck, Tübingen.
Greer, J.M., The Corpus Hermeticum and Hermetic Tradition, viewed 17 May 2010, from http://www.gnosis.org/library/hermet.htm

Gruenler, R.G., 1989, 'John 17:20-26', Interpretation 43(2), 178-183.

Hendriksen, W., 1976, Gospel of John, Banner of Truth, Edinburgh.

Hesselgrave, D.J., 2000, 'Essential elements of church planting and church growth in the 21st century', Evangelical Missions Quarterly 36(1), 24-32.

Hoeller, S.A., 1996, On the trial of the Winged God. Hermes and Hermeticism throughout the Ages, viewed 17 May 2010, from http://gnosis.org/hermes. htm\#notes

Jacobs, L., 2007, Wat sê Joh. 17 oor kerkeenheid?, Die Kerkbode, 08 Junie, p. 7.

Käsemann, E., 1970 [1960], 'Begründet der neutestamentliche Kanon die Einheit de Kirche?', in E. Käsemann (Hrsg.), Das Neue Testament als Kanon, pp. 124-133, Vandenhoeck \& Ruprecht, Göttingen.

Käsemann, E., 1970, Das Neue Testament als Kanon, Vandenhoeck \& Ruprecht, Göttingen.

Kysar, R., 1984, John's story of Jesus, Fortress, Philadelphia.

Lozada, F. \& Thatcher, T. (eds.), 2006, New currents through John: a global perspective, SBL, Resources for biblical study No. 54, Society of Biblical Literature, Atlanta.

Mack, B.L., 1996, Who wrote the New Testament? The making of the Christian Myth, Harper, San Francisco.

Malatesta, E., 1971, 'The literary structure of John 17', Biblica 52(3), 190-214.

Malina, B.J., \& Rohrbaugh R.L., 1998, Social-Science Commentary on the Gospel of John, Fortress, Minneapolis.

Malina, B.J., 2001, The social gospel of Jesus. The Kingdom of God in Mediterranean perspective, Fortress, Minneapolis.

Petersen, N.R., 1985, Rediscovering Paul. Philemon and the sociology of Paul's narrative world, Fortress, Philadelphia.

Reinhartz, A., 2001, Befriending the Beloved Disciple. A Jewish Reading of the Gospe of John, Continuum, New York.

Robinson, J.A.T., 1959, 'The New Look at the Fourth Gospel', Studia Evangelica 1(1959), 338-350.

Smalley, S.S., 1983, John - Evangelist and Interpreter, Paternoster Press, Exeter.

Smith, D.M., 1986, John. Proclamation Commentaries, 2nd rev. edn., Fortress, Philadelphia.

Suggit, J.N., 1992, 'Rhetoric of the Word. An interactional analysis of the Lord's Prayer in John 17 and its communicative implications', Neotestamentica 26(1), 47-58.

Thatcher, T., 2006, 'The New Current through John: The old "New Look" and the New Critical Orthodoxy', in F. Lozada \& T. Thatcher (eds.), New currents through John: a global perspective, pp. 199-209, SBL, Resources for biblical study No. 54, Society of Biblical Literature, Atlanta.

Tolmie, D.F., 1993, 'A discourse analysis of John 17:1-26', Neotestamentica 27(2), 403-418.

Wendland, E.R., 1992, 'Rhetoric of the Word. An interactional discourse analysis of the Lord's Prayer of John 17 and its communicative implications', Neotestamentica 26(1), 59-88.

Wong, C.H., 2006, 'The structure of John 17', Verbum et Ecclesia 27(1), 374-392.

Zimmermann, R., 2006, 'Imagery in John: Opening up paths into the tangled thicket of John's figurative world', in J. Frey, J.G. Van der Watt \& R. Zimmermann (eds.), Imagery in the Gospel of John, pp. 1-43, Wissenschaftliche Untersuchuningen zum Neuen Testament 200, Tübingen, Mohr Siebeck. 